\title{
Artisans and the Marketing of Ethnicity: Globalization, Indigenous Identity, and Nobility Principles in Micro-Enterprise Development
}

\author{
Robin M. Chandler, Ph.D. \\ Northeastern University
}

\section{Ethnicity 2007}

As a constructed category of human difference, 'ethnicity' has given way to 'culture' in its shared genealogy in the new millennium. Public knowledge about such phenomena as 'ethnic cleansing', debates on immigration, and the use of ethnicity as both a dependent and independent variable in research and policy are central realities in the domestic and foreign policies of many nations. The social psychology of group affiliation, nationalism, and the use of ethnicity (as well as gender) in workplace diversity, or the deployment of ethnicity in electoral politics continues to perplex and complicate human social interaction.

One of the anomalies of culture as a way of life among 'subcultures' is the degree to which ethnic differences constrain or expand human freedom and the right of access to the benefits and resources of the planet. Globalization and transnationalism, in particular, has affected the way culture-as-difference is deployed in identity politics and the manipulation of culture in the reconstruction of societies (Yúdice, 2003).

Race or ethnicity is often a marker of advantage or disadvantage. Structured inequalities, over consumption, and the competition for scarce resources. Social conflict and political unrest only further exacerbate the possibilities of economic freedom for the poor and deepen the economic divide creating dimensions of stratification based on power, privilege, and prestige. Conventional social science has examined these challenges historically, but the new globalization of capitalization and increasing political tensions among governments have caused many social advocates, non-governmental organizations, and financial institutions to take their case to the micro-level in a bid to alleviate poverty through small business development -microenterprise from rural settlements to the urban centers. This has led to a confrontation with indigenous knowledge and indigenous people. The question is when and where ethnicity or culture 
is compatible or oppositional to commerce. Who are these ethnic entrepreneurs and do they control the course of their ethnic traditions in the new market economy?

Philosophical ideas concerning race were formulated by academic disciplines in nineteenth century followed by new knowledge about the seemingly infinite range of ethnic groups identified at the height of imperialism. Social science and anthropology have claimed two streams of thinking on how ethnicity is defined. One stream of thought characterizes ethnicity and its derivations to common descent and cultural continuity. Another focuses on other distinct markers such as phenotype (physical appearance), name, language, history, and religion, factors formerly associate with race. Globalization has expanded how individuals define themselves as well as how state institutions define them. In any case, the indigenous is experienced as ethnic and, therefore, both are part of the long-standing colonial relationship. The heritage debates located in the tourism industry involve not only the rights of ethnic peoples (human and intellectual), but create a striking convergence with issues of environmentalism, fair trade, and sustainability. What further complicates these social and economic relations is the correlation between ethnic groups and poverty and the new income-earning potential of ethnicity in the handicrafts industry. Some critics refer to links between tourism as an extension of neocolonialism in the developing world. (Boniface and Fowler, 1993) Therefore, the question of ethnicity and artisans may be reframed as an indigenous/colonial relationship, one which exposes the possibilities of the western/elite consumer once again pursuing those objects of pleasure and desire once promoted as "the exotic other." Within international development, however, there exist genuine commitments to the alleviation of poverty and numerous social and financial organizations have made their mark, some well before the inauguration of the UN Millennium Development Goals.

In this essay ethnicity is being presented as an aspect of economic mobilization in the developing world and in emerging economies specifically focused on material culture as a product of ethnicity in the handicrafts industry. Historically, material culture, particularly crafts have played a diminishing role in the GNP of many countries because they have been situated in the informal sector, undervalued as 'folkways', or associated with 'women's domestic work', thus unaccounted for in the formal economic picture. Further, the emergence of credit options for the poor, prominently associated with the Grameen Bank in Bangladesh, suggested new banking models from the World Bank to national financial systems of microfinance. Besides ethnicity then, the poor have become a target market for micro-finance institutions, where a century ago it was assumed that the poor were bad financial risks having no collateral besides their labor. How we define and value different types of human labor appears to occur in renewable cycles.

An insinuating industrialization and the demand for mechanized goods marginalized the cottage industries as labor-intensive industries that focused on the hand manufacture of products associated with rural life and cultural heritage. A timeconsuming process, the production of handicrafts as rare objects of personal consumption eventually lost their niche markets and patrons with few exceptions. As a result many of these industries died out from the silk-weaving tradition of Laos to the pottery-making traditions of the Amazon region, or the sculptors of Tengenengue in Zimbabwe. However, to focus on not merely the artisan industries but the artisans themselves reveals shifts in how we think about ethnicity in the new millennium. As such, identity issues, the sense of ethnic self, and the preservation of that sense of 
ethnic traditional ways though that priceless social product-the craft- represents the central preoccupation of current theory, practice, and policy among these small business artisans and the legion of international social entrepreneurs who are providing capacity-building skills to these artisans.

Whether, this occupational interest in artisans and their traditional crafts is seen as ethnic exploitation by formal organizations, capitalistic institutions, or by the altruistic values of a new generation of social entrepreneurs, the private ownership of production, the revitalization of ethnic values, and the spiritual focus on the essential nobility of men and women, especially the poor, is creating new forms of social cohesion, economic empowerment, and a resurgence of interest in the professional artisan in the social hierarchies of many local communities in developing nations. Artisans are achieving a new spiritual status all over the world, one that elevates not only their social and economic conditions, but also their role as players in cultural continuity

\section{Ethnic Artisans}

Ethnic artisans are defined as native-born producers of indigenous handicrafts and other culturally specific products in developing nations who self-identify as 'native' or 'indigenous'. In the ancient world, east and west, an individual who possessed artisan skills were part of a merchant class who were servants to kings, emperors, rulers, chiefs, sheiks and pharaohs alike. The production of art and artifacts is a much older project that dates to pre-literate societies engaged in traditional ideas concerning "faber", the making of objects both utilitarian and aesthetically unique.

By the middle ages, artisans became associated with the guild system, an intricate network of master artisans who were "licensed" by local and national authorities. The guild system existed from Europe, to Japan's Edo period, to the court artisans of Ife and Benin in medieval Mali and Songhay. This system was partly a selfregulating association that administered quality control, managed all components of production and distribution, and provided protection from competitive markets. One passed through stages of professional growth from apprentice to journeyman, from journeyman to master artisan, the latter accredited through the production of a "masterpiece". Individual artisans, guilds, or artisan families gained reputation and status by creating objects that met the standards of the guild or court, but extended the bar to produce unique objects that defined personal style becoming the signature of the artisan, both male and female, or of a family.

Cultural transmission of knowledge and technique become key factors in how ethnic artisans learned and passed on the making of their craft. As master craftsman and craftswoman, artisans provided the aesthetic labor necessary for the construction of both objects and ceremonies that preserved national and group identity through statesponsored and religious patronage. The master-apprentice model, guild systems, and indigenous knowledge that characterized old world development among artisans have given way to new forms of development. However, in many regions from Puerto Rico to Southeast Asia, artisan skills are passed down through families, extended family members, or young people in local communities. The Santeros of Puerto Rico, its lace bobbin weavers, and the Mascaras of Loiza, east of San Juan have become family traditions. Such practices of cultural transmission retain the creative wealth within communities in home-based enterprises in which mentoring and training workshops 
validate heritage and the production of handicraft objects. From a commercial standpoint, one of the primary interventions in the promotion of handicrafts has been a tourism sector. However, their focus has been on the promotion and sale of marketable objects selling ethnicity- and less on the capacity building of the artisan. Other organizations have increasingly stepped up to provide more comprehensive social and business development skills to assist artisans in meeting the demands of small businesses in the global market. Browse through the über-stylish pages of home furnishings, travel, and food industry journals for direct marketing advertisements by artisan industry brokers or the travel and tourism sections of popular newspapers who lure travelers to "exotic" destinations such as Istanbul and its 550 year old Grand Bazaar, the oldest and the largest covered market place in the world.

\section{Microenterprise as Development}

In the paradigm shift from traditional ways of life to modern ways of life, the imposition of western ideas on ethnic groups has been sweeping both in the way the west has defined wealth purely in economic terms and the press of globalization on a shrinking planet driven by overconsumption and underdevelopment. While the era of historical imperialism may have ended with the Age of exploration, the economic, political, and cultural engine of colonialism was driven by a need to exploit and subjugate both ethnicity and ethnic groups. The destructiveness of policies of imperialism and colonialism has been followed by what the western world now refers to as 'development'. The scope and scale of penetration into the financial world of poverty has been the work of micro-finance institutions (MFIs), commercial banks, and NGO's. Latin America has taken a lead in advancing small business loan opportunities for individuals and households who have "an established minimum capacity to repay a loan"(Acción, 2005). However, the economic realities of urban and rural poverty are regionally dependent. In Africa and Asia, most of the poor reside in rural areas, while in Latin America "The majority of the poor live in urban areas while at the same time the poorest people live in rural areas (ibid). By 2002 the distribution of extreme poverty in Latin America including the Caribbean was $13+\%$ in urban areas and $37+\%$ in rural areas. "Indigence" in both rural and urban settlements is, therefore, conditional on region. However, microcredit clients in the artisan sector have emerged as sustainable phenomena in Latin America, Asia, Africa, and increasingly in the Middle East as ethnicity and cultural heritage become policy magnets. Data collected on specific artisan industries points to the dynamism of integrated approaches to social and economic empowerment of low-income families and the poor. However, the role that women have been playing in the economic activity of their local and national artisan industries including the informal sector is gaining significant momentum. Historically, women's work as often been relegated to the informal sector. Not until 1993 were international statistical definitions of informal sector employment adopted and fewer than 100 countries provide national statistics since 1995. The difficulties in quantifying the contributions of women to the artisan industries of developing nations that lack statistics are an inherent drawback in measuring their labor as artisans. The larger goals of collecting data by sex in order to monitor comparative wage earnings between men and women, while increasing, do not pull out the occupational output of artisans. This data frequently shows up conflated with tourism statistics or in individuated NGO reports. However, the numbers of handicraft workers across countries and regions as exemplars of the growing interest in stimulating entrepreneurialism among the poor, especially 
women continue to grow. Here are some reasons why women dominate and thrive in artisan industries.

\section{Women-Surviving and Thriving}

By the late 1990's the World Bank and other international and national aid agencies recognized that women, especially poor and low-income women, were dependable financial risks. A now growing revolution in universal banking models that historically preferred assets or capital as collateral for loan-making, poor and lowincome women are now playing a competitive role as full participants in small business owners in the developing world. The loan repayment rate of microcredit loans reported by MFl's has surpassed more than $98 \%$ as generally reported by the Grameen Bank, Acción, and Finca, leaders in the microfinance movement. However, beyond the economic factors that have made artisan industries sustainable, the role of women as central agents in the lives of families and communities is increasingly evident. Homebased entrepreneurs (HBE's) are a critical sector of developing nation economies as prospective clients in artisan industries. As artisans, many have been the recipients of handicrafts traditions transmitted from master craftswomen or are newly trained in the revival of traditional crafts once central features of their ethnic groups.

Globally, gender, the role of women's empowerment schemes, and the political nature of gender inclusion from a human rights and governance point of view are increasing foci. Barriteau (2001) looks at the Caribbean political economy and gender and Otero (1998) follows gender-related policymaking and Mf. To further document the history of artisans and ME. Nearly $85 \%$ of the world's poor live in developing nations. The 'feminization of poverty' describes the disproportionate effects pf poverty on women and children. Due to transportation challenges between rural and urban markets and the prominence of street vendors (male and female), house-bound constraints of (e.g., Moslem) women and the resulting home-based (formerly cottage industries), lack of access to equal education and training, the home-based sector, street vendors, the informal economy, and the cooperative have been viable labor sites in which women artisans can participate in local economies. (FN-See Strassmann (1987), Cross (1998), Ehlers (2000), Bartra (2003) for research on these categories of labor participation and the stresses on moving handicrafts to local markets. Tourner and Fouracre (1995) address the challenges of differential transport access for women particularly in developing nations and the need for gender awareness in developing policies of urban planning that overcome the lack of access to safe, affordable, and efficient transport. Further, advances in e-commerce can, in some cases, reduce the reliance on conventional transportation for all entrepreneurs.)

\section{Critiques of ethnic-based micro-enterprise}

Critics of microenterprise and microfinance suggest that 1) small-scale businesses will not necessarily move the national economies of developing nations and 2) that, perhaps, direct giving (philanthropy) may be a better route to reversing the entrenched, transgenerational, and historical poverty present in many countries. It is possible that a whole scale reversal of poverty and its long-term effects can no more be reversed than global warming. The primary concern here is ethnicity. 
Entrenched poverty is primarily characterized by race-based, ethnically rooted deprivation and inequality and the systematic underdevelopment of ethnic communities globally. From this vantage point, the current fever of (over) development appears as a continuation of the exploitation (of ethnic artisans in this case) to satisfy the insatiable demands of the global market.

While the study of race and culture may seems an embedded or implicit correlative with poverty in many nations, the way that race or culture-based poverty operates, particularly among artisans has yet to be directly addressed. This is for several reasons:

1) Increasingly, studies bypass race in favor of cultural identity as a variable of policy interest;

2) Income generated by artisan industries is not often incorporated in the databases of developing nations, unless it is conflated with tourism or the new formula called "creative industries;

3) "Creative industries" policies are initially associated with fine arts and entertainment (music, theatre, and film) and have distinct differences as economic industries

4) A shift in focus to gender-focused policy initiatives has weighed in on gender, but not always gender and race as "double jeopardy" in poverty studies;

5) Marketing ethnicity as "cultural heritage" content for the tourism industry and as global policy development sheds light on the priorities of philanthropists and entrepreneurs, economists, and activists in the developed world. A critical perspective of artisans themselves is missing

\section{Conclusion}

From the global vista, UNESCO's Global Alliance for Cultural Diversity (ACP countries-African, Caribbean, Pacific) with ILO (International Labor Organization) and UNCTAD has been investigating key elements of how nations preserve culture. The international policy framework of "Intangible Heritage" and "Living Human Treasure" are preservation measures that seek to associate human rights and diversity with the endangerment of ethnic heritage in a time of globalization. And given the enormous challenges of reducing and eliminating global poverty in a market economy matrix, many social scientists, human rights and legal advocates, and development economists have addressed the related issues of social inequality and injustice which are at the heart of the structural inequalities that plague both developing and developed nations. Luttrell and Dickson (1999) discuss corporate and government social responsibility models, fair trade practices, and their impact on artisans industries. In a treatise on trade and social justice and Bhala (2003) has considered how the international development community participates in and confronts national, global, and local policies that purport to enhance access to justice for the 'have-nots'. There is no dearth of writing and research on how to reduce poverty and eliminate it. However, I would argue that poverty reduction must move in tandem with wealth reduction. Microenterprise among ethnic artisans is, beyond its critics, producing profound opportunities for artisans to remain in rural areas, preserve their traditional knowledge, and offers new insights into the essential nobility through innovative human economic occupational development. 


\section{General References and Suggested Reading}

Aageson, T.H. (1999). "Puerto Rican Artisan Sector: Observations and Recommendations". Farmington, CT:Aid to Artisans. June 7-9.

Aid to Artisans -From Market to Market Report(2003) Summer: 8-9.

Aid to Artisans -From Market to Market Report(2003) Summer: 8-9.

“Artisanía de Puerto Rico”. Vega and Rosado. San Juan: Fomento, 1997.

Ballengee-Morris, C. (2002). Cultures for sale: Perspectives on colonialism and selfdetermination and the relationship to authenticity and tourism. Studies in Art Education, 43(3), 232-245.

Balo, E. (2003). "El microcrédito es el único medio real para erradicar lo pobreza (Joana Caparrós)" AR-revista, septiembre: 42-43.

Barriteau, E. et al (2001). The political economy of gender in the twentieth-century Caribbean. New York : Palgrave.

Bartra, E., Ed. (2003). Crafting Gender (Women and Folk Art in Latin America and the Caribbean. Durham and London, Duke Univ ersity Press.

Bhala, R. (2003). Trade, development, and social justice. Durham, N.C.: Carolina Academic Press.

Boniface, P. and Fowler, P. J. (1993).Heritage and Tourism in the global village'. New York: Routledge.

Butler, R. (2006). "Handmade in Oaxaca-Heart of Native Mexico," Native Peoples (Arts and Life ways). . Vol XIV,No.2, March/April: 22-28.

Chandler, R. (2004)“Micro-Enterprise 2004: Women, Development \& Poverty Elimination: Case Studies in Artisan Industries", Presentation/Lecture Series, Northeastern University, March 8.

Chebair, E.R. and Reichmann,R. (1995) Balance of the Double Day: Women as Managers of Microenterprises. Monograph Series No.10. Cambridge (MA): Accion International, May.

Clifford, J. (1988). The Predicament of Culture: Twentieth Century Ethnography, Literature, and Art. Cambridge: Harvard University Press.

Cockram,M. (2005). "Lessons learned in Twenty Years (Honduras, Ghana, Hungary, Russia, Armenia, Central Asia, and Peru", Aid to Artisans Report, October 31.

Coleman, I, (2004). ‘The Payoff From Women's Rights”, Foreign Affairs. May/June: 8095. 
Cosgrove, C. ( 1999). "Give Them the Credit They Deserve: Market Women and the Impact of Micro-enterprise Lending in the Municipalities of Apopa and Nejapa, El Salvador". Dissertation. Northeastern University,Department of Sociology and Anthropology.

Cross, Jihn C. (1998). Informal Politics: Street Vendors and the State in Mexico City. (Stanford: Stanford University Press.

Egan, Tmothy. "Indian Reservations Bank on Authenticity to Draw Tourists," New York Times. September 21, 1998.

Ehlers, T.B. (2000). Silent Looms: Women and Production in a Guatemalan Town. Austin: University of Texas.

Emmel, A. (2005). Taking Action in a Changing World. Oxford, UK: George Ronald.

Falú, Aixa M. (2004). Raza, género y clase social (el discrimen contra las mujeres afropuertorriqueñas. Bogotá: ALVI IMPRESORES LTDA.

Gewertz, D. and Errington, F. (1998). "Sleights of Hand and the Construction of Desire in a Papua New Guinea Modernity" in The Contemporary Pacific. Honolulu: University of Hawaii Press. Vol. 10, no. 2, Fall.

Hand/Eye (Aid to Artisans magazine). Fall 2007. http//:www.aidtoartisans.org

International Flows of Selected Cultural Goods and Services, 1994-2003. UNESCO Institute for Statistics ( UIS), Montreal , Quebec, Canada. 2005. pdf file at www.uis.unesco.org

Keller, Bill. "Touring South Africa's Black Townships", New York Times. February 6, 1994.

Kopytoff, Verne G. (1998). "Navajos Turning Hoguns Into B \& B's," New York Times. July 26 .

Luttrell ,Mary Ann and Dickson, Marsha Ann. (1999). Social Responsibility in the Global Market-Fair Trade of Cultural Products*. Thousand Oaks :Sage Publications.

Lynes , K. and Torry, G., Eds. (2005)/ From Local to Global: Making Peace Work for Women. NGO Working Group on Women, Peace and Security. Five Years on Report.

Marulanda, B. and Otero,M. ( 2005). "The Profile of Microfinance in Latin America in Ten Years:Vision \& Characteristics". Executive Summary Presentation and Study commissioned by Microcredit Summit, Latin America \& Caribbean Regional Meeting, April. [ Full Text of Study Available

at $<$ www.accion.org/more about microfinance

Morris, Jr, W. F. (1996). Handmade Money: Latin American Artisans in the Marketplace. Wash.D.C.: Organization of American States. 
Orbeta, Jr., A. (2001). Paper, "Action Research on E-Commerce for Small Artisans and Development Organizations: Pan Asia E-Commerce. International Development Research Centre /Pan Asia Netowrking programme.

Osburn, Margaret. "Along the Side of the Road: Crafting Sea Grass Baskets," American Visions. April 1988: 16-21.

Otero, María. (1998). "Policies to Empower Women," Address to ACCION International, Microcredit Summit, Meeting of Councils. June 27.

Poblete, J. (2003). Ed., Critical Latin American and Latino Studies. Minneapolis: University of Minneapoliss Press: 138-153.

Roads Toward Gender Equity in Latin America and the Caribbean. $9^{\text {th }}$ Annual Conference on Women in LAC. ECLAC. Mexico City, June 10-12 June 2004. [pdf format].

Sen, A. (1999). Development As Freedom. Amartya Sen. New York: Alfred A. Knopf.

Sieder, R., Ed. (2002). Multiculturalism in Latin America: Indigenous Rights, Diversity and Democracy. New York: Palgrave/MacMillan.

Trelles, E. ( 2004). “We the Women”. Latina, December 2003/ January:112-115.

Turner, Jeff and Fouracre,P.(1995). "Women and Transport in Developing Countries. UK: Transport Reviews.

Wood, W.W. (2000). "Stories from the Field, Handicraft Production, and Mexican National Patrimony: A Lesson in Translocality From B. Traven(1) in Ethnology. Pittsburgh:University of Pittsburgh Press. Volume: 39. Issue: 3: 183-

Yúdice, G. (2003). The Experiency of Culture: Uses of Culture in the Global Era. Durham: Duke University Press.

Yunus, M. (2003). Banker to the Poor: Micro-lending ad the battle against world poverty. New York: Public Affairs/Perseus Books Group. 